\title{
Unexplained persistent gross hematuria in pregnancy
}

\author{
Baafuor K. Opoku \\ Correspondence: baafuoropoku@yahoo.com

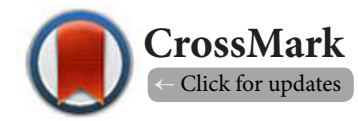

Department of Obstetrics and Gynaecology, Kwame Nkrumah University of Science and Technology, Kumasi, Ghana.

\begin{abstract}
Causes of hematuria outside pregnancy are all implicated in hematuria occurring in pregnancy in addition to pregnancy-specific causes such as pre-eclampsia and placenta percreta. When no organic cause is found, hematuria is classed as Idiopathic. Most authorities believe idiopathic hematuria is due to peculiar changes in the urinary tract resulting from mechanical and hormonal factors related to pregnancy. Such hematuria usually begins in late second trimester through the third trimester and resolves after delivery. A case is presented of idiopathic hematuria in a 33-year old mother of 3 whose hematuria resolved at 34 weeks as abruptly as it had started at 18 weeks in pregnancy. Clinical features suggest the cause to be the Nutcracker phenomenon. The need for noninvasive investigations and conservative management is stressed as well as the rarity of such cases resolving before delivery.
\end{abstract}

Keywords: Hematuria, pregnancy, idiopathic, nutcracker phenomenon

\section{Background}

While microscopic or dipstick hematuria is common during pregnancy, it rarely signifies any condition likely to impact negatively on pregnancy outcome [1]. Gross hematuria on the other hand is rare in pregnancy. The commonest etiology is infection, followed by bladder stones, underlying renal disease, medications, trauma, tumors and obstruction $[2,3]$. Some drugs such as rifampicin and phenytoin can also discolor urine and give an impression of gross hematuria. Differential diagnoses include all the causes of hematuria in the non-pregnant patient as well as pregnancy-specific causes such as pre-eclampsia and placenta percreta. Investigations during pregnancy to find the cause are limited to non-invasive procedures which include blood and urine tests, sonography and sometimes, magnetic resonance imaging.

If investigations yield no known cause, the hematuria is labeled as "Idiopathic" and is explained by the peculiar changes in the urinary tract due to mechanical and hormonal factors related to pregnancy [4].

Such pregnancy-induced hematuria is almost invariably associated with spontaneous and complete resolution after delivery [5]. Hematuria may or may not recur in future pregnancies. A case is presented of a patient who had persistent gross hematuria in pregnancy of no pathologic cause that persisted for 16 weeks and resolved spontaneously at 34 weeks as abruptly as it had started.

\section{Case report}

A 33-year old para 3 all alive, whose last child was 2 years old reported to Komfo Anokye Teaching Hospital for routine an- tenatal clinic in July 2012 at 14 weeks. Apart from nausea she was well. Her blood pressure was $120 / 70 \mathrm{mmHg}$. Her booking $\mathrm{Hb}$ was $13.2 \mathrm{~g} / \mathrm{dl}$ and the blood group B Rh 'D' negative.She was sickling negative (genotype AA). She had received Anti-D Immunoglobulin at the last delivery and currently had negative indirect agglutination test (IAT). She was given routine prenatal drugs of fersolate, folic acid and multivitamin tablets and scheduled for the next visit in a month's time.

She was next seen as scheduled with a 2-day complaint of gross hematuria without lower abdominal pains or dysuria. The hematuria was frank and neither initial nor terminal. She had no fever or chills and no history of trauma. She had no history of a bleeding disorder and was not on any medication apart from the prenatal drugs given at the booking visit. She had a $\mathrm{BP}$ of $120 / 80 \mathrm{mmHg}$ and an $\mathrm{Hb}$ of $12.6 \mathrm{~g} / \mathrm{dl}$. She was not febrile. There was no lower abdominal or renal angle tenderness. A speculum examination showed normal vulva and vagina and no abnormality on the cervix. A Foley's catheter passed yielded bloody urine, a specimen of which was taken for microbiology. An obstetric ultrasound scan confirmed an 18 weeks + 3days live, active fetus and a fundal placenta. Patient was admitted for observation and monitoring, and started on hematinics.

The full blood count and clotting profile showed no abnormality. Serum urea, creatinine and electrolytes were all normal. Urine analysis showed RBC $>200 / \mathrm{hpf}$ and no casts, eggs or ova. Culture yielded no bacterial growth after 7 days incubation. A urological scan done 2 days later reported as follows:"normal kidneys and ureters, normal urinary bladder contour, no mass or tumor noted; there is debris at the bladder base consistent with hematuria; post void volume is small and 
normal". Urine cytology was normal, showed squamous cells and no malignant cells.

The findings were discussed with the patient who was reassured that all was well. She however, continued to have persistent gross hematuria. Her $\mathrm{Hb}$ dropped to $10.8 \mathrm{~g} / \mathrm{dl}$ after a month, and a further drop to $9.6 \mathrm{~g} / \mathrm{dl}$ after 2 months. She showed no symptoms of anemia, however. Abdominal examinations showed normal fetal growth. A repeat urine analysis after a month of admission showed RBC $>250 / \mathrm{hpf}$ and no bacterial growth on culture.

At 32 weeks her $\mathrm{Hb}$ had further dropped to $8.7 \mathrm{~g} / \mathrm{dl}$. Her IAT was negative. She was transfused 3 units of whole blood. Hematuria continued till 34 weeks +5 days when there was an abrupt cessation. Urine analysis after that was negative. $\mathrm{Her} \mathrm{Hb}$ was $10.4 \mathrm{~g} / \mathrm{dl}$. A repeat obstetric scan at 36 weeks confirmed a fundal placenta. She went into spontaneous labour at 39 weeks +4 days and delivered a live female baby weight $2.9 \mathrm{~kg}$ with Apgar scores 8 and 10 at 1 and 5 minutes respectively. The baby's blood group was $B \mathrm{Rh}$ ' $\mathrm{D}$ ' positive. The patient was therefore given 1500 IU of Anti-D Immunoglobulin and discharged in good condition with an $\mathrm{Hb}$ of $10.1 \mathrm{~g} / \mathrm{dl}$. A flexible cystoscopy done at 2 months postpartum showed no abnormality.

\section{Discussion}

Whilst microscopic hematuria, defined as three or more redblood cells (RBCs) per high power field on microscopic evaluation of urinary sediment from two of three properly collected urinalysis specimens [6] is relatively common in pregnancy, macroscopic or gross hematuria (visible to the naked eye) is rare. The 'Nutcracker' theory $[7,8]$ also called Left renal vein Hypertension, has been used to explain idiopathic hematuria of pregnancy. The phenomenon is attributable to the idiopathic decrease in the angle between the aorta and the superior mesenteric artery with consequent compression of the left renal vein leading to an increased resistance to venous outflow (Figures 1 and 2). This results in development of extensive collateral venous drainage system involving the gonadal capsular, suprarenal, lumbar, azygous and peri-ureteral veins. The resulting extensive renal varicosities give rise to hematuria when the thin-walled septum separating the veins from the collecting system ruptures. The main presenting symptom is hematuria, with or without left flank pain.

This patient presented with a sudden onset of gross hematuria at 18 weeks and had no pathologic cause identified. The recommended investigations of full blood count, clotting parameters, urinalysis, renal function tests, ultrasonography and cystoscopy proved negative. Although confirmatory tests such as renal venography with measurement of pressure gradient between left renal vein and inferior vena cava, was not done, she fitted clinically into the Nutcracker phenomenon. Unlike documented cases of idiopathic hematuria which resolve after pregnancy, her condition abruptly resolved at 34 weeks. Other documented rarer causes of hematuria in

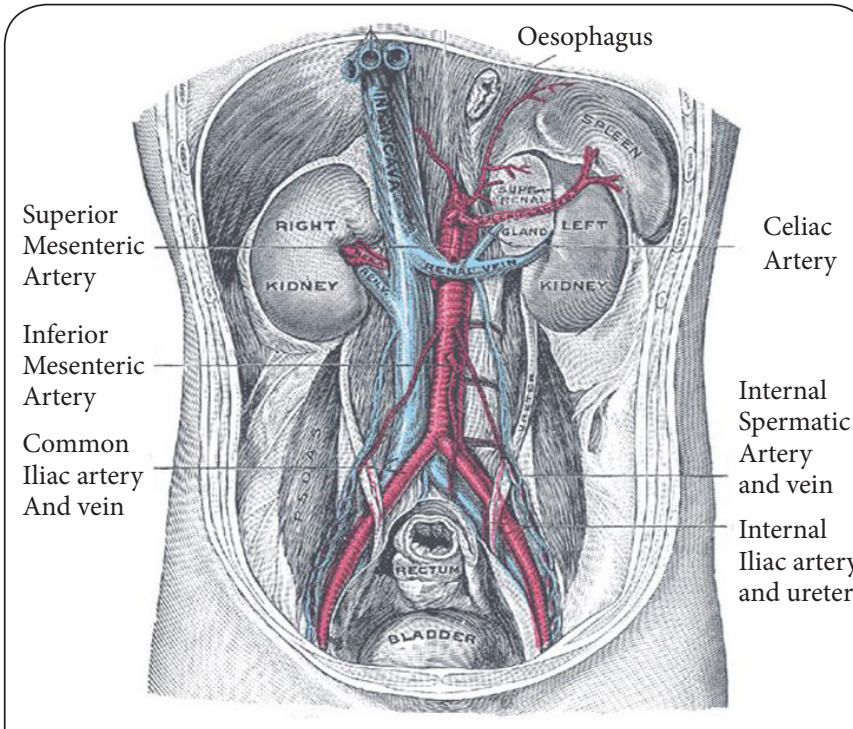

Figure 1. Showing position of the superior mesenteric artery in relation to the left renal vein.

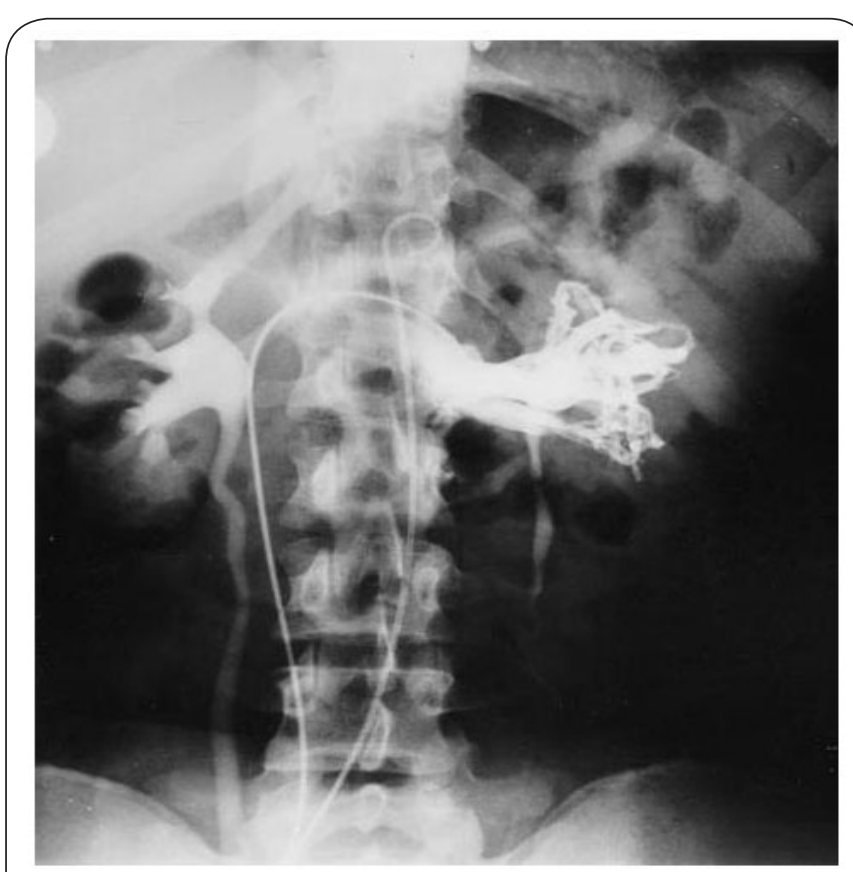

Figure 2. A venography showing dilatation and extensive collateral formations of the left renal vein tree in the Nutcracker phenomenon.

pregnancy include the Youssef syndrome [9], paragangliomas [10], renal arterio-venous malformations [11], molar pregnancy [12] and the Nutcracker syndrome $[13,14]$.

She was managed in hospital under strict observation and had repeated investigations to try and find the cause of the hematuria. Blood was only transfused when her $\mathrm{Hb}$ dropped below $9.0 \mathrm{~g} / \mathrm{dl}$. She delivered spontaneously to a 
normal, average weight baby at 39 weeks.

Such gross hematuria usually causes great anxiety for the patient who needs reassurance at all times for a favorable outcome. She was consistently reassured of her condition. Any other investigations other than those listed earlier can safely be deferred till after the puerperium.

Outside pregnancy, procedures such as Gortex graft vein interposition, nephropexy, stenting, and kidney auto-transplantation can be used to correct the Nutcracker phenomenon [15].

\section{Conclusion}

When idiopathic hematuria occurs in pregnancy, the Nutcracker phenomenon must be thought of. Non-invasive investigations are recommended, as well as symptomatic treatment in hospital. Although the hematuria is known to resolve after delivery, it can also resolve during pregnancy as this case has revealed.

\section{Competing interests}

The author declares that he has no competing interests.

\section{Acknowledgement}

I express my sincere appreciation to the patient who willingly agreed to have her case presented to advance the cause of knowledge in medicine.

\section{Publication history}

Editor: Christos lavazzo, Royal Surrey County Hospital, UK. Received: 16-Dec-2013 Accepted: 11-Jan-2014

Published: 23-Jan-2014

\section{References}

1. Brown MA, Holt JL, Mangos GJ, Murray N, Curtis J and Homer C. Microscopic hematuria in pregnancy: relevance to pregnancy outcome. Am J Kidney Dis. 2005; 45:667-73. | Article | PubMed

2. Lindheimer MD and Davison JM. Hematuria in pregnancy. Principles and Practice of Medical Therapy in pregnancy. Ed-Gleicher N, 3rd edition, Appleton and Lange, Connecticut. 1998; 1074-75.

3. Levey AS, Madaio MP and Perrone RD. Laboratory assessment of renal disease : Clearance, urinalysis and renal biopsy. The Kidney. Ed-Brenner BM, Rector FC. 4th edition. WB Saunders Company, Jovanovich. 1991; 2:948.

4. Danielli L, Korchazak D, Beyar H and Lotan M. Recurrent hematuria during multiple pregnancies. Obstet Gynecol. 1987; 69:446-8. | Article | PubMed

5. Sandhu KS, LaCombe JA, Fleischmann N, Greston WM, Lazarou G and Mikhail MS. Gross and microscopic hematuria: guidelines for obstetricians and gynecologists. Obstet Gynecol Surv. 2009; 64:39-49. I Article I PubMed

6. McDonald MM, Swagerty D and Wetzel L. Assessment of microscopic hematuria in adults. Am Fam Physician. 2006; 73:1748-54. I Article | PubMed

7. de Schepper A. ["Nutcracker" phenomenon of the renal vein and venous pathology of the left kidney]. J Belge Radiol. 1972; 55:507-11. | PubMed

8. Wendel RG, Crawford ED and Hehman KN. The "nutcracker" phenomenon: an unusual cause for renal varicosities with hematuria. $J$ Urol. 1980; 123:761-3. | PubMed

9. Youssef AF. Menouria following lower segment cesarean section; a syndrome. Am J Obstet Gynecol. 1957; 73:759-67. | PubMed
10. Demirkesen O, Cetinel B, Yaycioglu O, Uygun N and Solok V. Unusual cause of early preeclampsia: bladder paraganglioma. Urology. 2000; 56:154. | Article | PubMed

11. Crotty KL, Orihuela E and Warren MM. Recent advances in the diagnosis and treatment of renal arteriovenous malformations and fistulas. $J$ Urol. 1993; 150:1355-9. | PubMed

12. Han BG, Kim MH, Karl EH, Hong SW and Choi SO. A case of membranoproliferative glomerulonephritis associated with a hydatidiform mole. Yonsei Med J. 2000; 41:407-10. I Pdf I PubMed

13. Sato $Y$, Yoshimura A, Sakai H, Yogi S, Kai Y and Ideura T. [A case of posterior nutcracker syndrome occurring in pregnancy]. Nihon Jinzo Gakkai Shi. 1997; 39:790-3. I PubMed

14. Uzu T, Ko M, Yamato M, Takahara K and Yamauchi A. A case of nutcracker syndrome presenting with hematuria in pregnancy. Nephron. 2002; 91:764-5. | Article | PubMed

15. Russo D, Minutolo R, laccarino V, Andreucci M, Capuano A and Savino FA. Gross hematuria of uncommon origin: the nutcracker syndrome. Am J Kidney Dis. 1998; 32:E3. I Article I PubMed

\section{Citation:}

Opoku BK. Unexplained persistent gross hematuria in pregnancy. Res J of Womens Health. 2014; 1:1. http://dx.doi.org/10.7243/2054-9865-1-1 